Mesopotamia J. of Agric.

Vol. (48)

\title{
CORRELATION AND PATH COEFFICIENT ANALYSIS IN BREAD WHEAT
}

\author{
S. M. Younis Al-Najjar \\ Kh. M. D. Al-Zubaidy \\ Field Crop Department, College of Agriculture and Forestry, University of Mosul \\ Profkhalid1953@gmail.com
}

\begin{abstract}
Fifteen genotypes of bread wheat in addition to the two local varieties (Sham6 and AbuGraib3) were planted inside Mosul University under three spaces between rows (15, 25 and $35 \mathrm{~cm}$ ) using split plots system in randomized complete block design with three replications to evaluate grain yield and some of its components (plant height, number spikes, number of grains/spike, biological yield, 1000 grain weight and harvest index), and genotypic and phenotypic path coefficient analysis among grain yield and its components. The results showed that $15 \mathrm{~cm}$ row space gave highest means for biological yield, number spikes and grain yield. The grain yield at this row space was $59.378 \%$ and $123.422 \%$ higher than that at 25 and $35 \mathrm{~cm}$ row space respectively. Some genotypes significantly outperformed for larger number of traits including grain yield, came in the forefront of it MEXIPAK 65/ASFOOR-7, and Sham6 followed by the genotypes PBW343, NESMA*2/14-2//2*SAFI3 and BT1735/ACHTAR//ASFOOR-1. It was shown that the yield/unit area had significant positive genotypic and phenotypic correlations with plant height, biological yield, number of grains/spike, 1000 grain weight and harvest index, and phenotypically with number of spikes per unit area. It was revealed from path coefficient analysis that number of grains/spike and harvest index had higher genetic and phenotypic direct effects and indirect effects through some other traits on grain yield, followed in importance by biological, this is useful in the reliability of these three traits as selection criteria for higher yield performance in breeding programs.
\end{abstract}

Key words: bread wheat, path coefficient, correlations

Received: 8/1/2020 , Accepted 3/3/2020

\section{INTRODUCTION}

Bread wheat (Triticum aestivum L.) is an important strategic crop in most countries of the world, and the process of developing new varieties of the crop characterized by high production specifications and good quality characteristics of the most important objectives sought by plant breeders. It is possible to improve crop yield using available genetic resources and by recognizing the nature and importance of genetic variations in the population, and that estimating genetic differences is a prerequisite for planning an appropriate breeding method. A careful look at the importance of genetic variations in crop species is also of paramount importance in that it provides a fundamental basis for an effective selection process, and to practice an effective selection prosses, determining the outcome of the crop is desirable. Correlations between traits are a measure of the strength of their relationship, and their knowledge between traits is important in plant breeding. If two traits are positively correlated, one can be indirectly improved by improving the other. The correlation coefficient would be useful if indirect selection of the secondary trait would be Part of M.Sc. Thesis for the first researcher 
Mesopotamia J. of Agric.

ISSN: $2224-9796$ (Online)

Vol. (48) No. (1) 2020

ISSN: 1815 - $316 \mathrm{X}$ (Print)

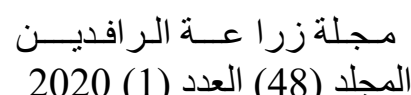

used to improve the essential trait beneficial (Hussain et al., 2010). The estimation of the correlation coefficient is necessary to develop a selection index, and in order to create a sense for correlation, Wright (1921) developed a path coefficient analysis method which was used to develop criteria for selecting complex traits in many crop (Dewey and Lu, 1958; Diz et al., 1994; Kang et al., 1983; Pandey and Torrie, 1973). This analysis provides effective means by estimating the direct and indirect causes of correlations (Kale et al., 2007). The method of analyzing the path coefficient in wheat was adopted by many researchers, Dutamo et al. (2015) from an experiment carried out in one location and from its use of the path coefficient analysis indicated that the two traits, harvest index and biological yield showed direct and indirect effects on the yield, and reliable In the selection for high yielding, but the final conclusion can only be judged once the experiment is repeated at multiple locations. Khan and Dar (2016) concluded that the analysis of path coefficient showed the higher importance of positive direct effect on grain yield by the number of spikes/plant_followed by number of grains/spike and 100 grains weight., Desheva (2016) reported from his study that the number of grains/spike and 1000 grains weight through the grains weight/spike had the highest positive indirect effect on the grain yield per plant, and this relationship can be used as a selectoral index in breeding studies to improve high-yielding varieties. The results of Sapi et al. (2017), Ayer1 et al. (2017) and Kamani et al. (2017) showed that the direct positive effect on the grain yield/plant was higher through biological yield and harvest index.

The aim of the study is to evaluate the yield and some of its components for fifteen introduced genotypes in addition to the two registered and certified in Iraq, Sham 6 and Abu Ghraib 3 at different spaces between rows and to partition the genetic and phenotypic correlation coefficients of grain yields with some of its components to direct and indirect effects.

\section{MATERIALS AND METHODS}

The experiment was carried out in the field of Field Crops Dept. (inside University of Mosul campus), and included the cultivation of 15 genotypes of bread wheat introduced from the International Center for Agricultural Research in the Dry Areas (ICARDA) in addition to the two registered and certified varieties in Iraq Sham 6 and Abu Ghraib 3 (their names and selection history are shown in table 1). The planting date was on December 7 , 2017 with the adoption of a seeding rate of $100 \mathrm{~kg}$ per hectare under rainy conditions, with supplementary irrigation simulating rain due to its receding during the season (Their quantities and dates are shown in Table 2), at three spaces of cultivation between rows (15, 25 and $35 \mathrm{~cm}$ ) using a split plot system by randomized complete block design with three replicates (planting spaces were distributed within each block in the main plots and genotypes in the split plots within each main plot, each block included 51 experimental units and each unit contained two lines with a length of $1.5 \mathrm{~m}$ for the line with no spaces between the experimental units. DAP fertilizer containing $\left(46 \% \mathrm{P}_{2} \mathrm{O}_{5}\right.$ and $\left.18 \% \mathrm{~N}\right)$ was added at a rate $200 \mathrm{~kg}$ per hectare during the preparation of the land for cultivation, and urea fertilizer $(46 \% \mathrm{~N})$ was added at a rate of $300 \mathrm{~kg}$ per hectare twice, the first after 45 days of planting and the second month after. At maturity, data were recorded on the traits of plant height $(\mathrm{cm})$, number of spikes $/ \mathrm{m}^{2}$, biological yield $\left(\mathrm{gm}\right.$ per $\left.\mathrm{m}^{2}\right)$, number of grains per spike, 
Mesopotamia J. of Agric.

ISSN: $2224-9796$ (Online)

مـجلة زرا عــة الر افديـن

Vol. (48) No. (1) 2020

ISSN: $1815-316 \mathrm{X}$ (Print)

المجلد (48) العدد (1) 2020

Table (1): Genotypes of bread wheat used in the study and their selection history.

\begin{tabular}{|c|c|c|}
\hline Seq & Name & Pedigree \\
\hline 1 & ATTILA-7 & $\begin{array}{l}\text { CM85836-50Y-0M-OY-3M-0Y-0SY- } \\
\text { OAP }\end{array}$ \\
\hline 2 & HAAMA-2/QAFZAH-16 & $\begin{array}{l}\text { ICW03-0184-13AP/0TS-0AP-0AP- } \\
\text { 8AP-0AP }\end{array}$ \\
\hline 3 & PASTOR-2/BOCRO-2 & $\begin{array}{l}\text { ICW03-0203-12AP/0TS-0AP-0AP- } \\
\text { 1AP-0AP }\end{array}$ \\
\hline 4 & HUBARA-5/3/SHA3/SERI//SHA4LLIRA & $\begin{array}{l}\text { ICW03-0041-10AP/0TS-0AP-0AP- } \\
\text { 3AP-0AP }\end{array}$ \\
\hline 5 & REYNA-12 & $\begin{array}{l}\text { ICW00-0634-3AP-0AP-0AP-39AP- } \\
\text { 0AP-0DZ/0 }\end{array}$ \\
\hline 6 & SEKSAKA-7/3/SHUHA-2//US732/HER & $\begin{array}{l}\text { ICW01-00054-0AP-11AP-0AP-0AP- } \\
\text { 14AP-16AP }\end{array}$ \\
\hline 7 & ANGI-5/ZEMAMRA-8 & $\begin{array}{l}\text { ICW03-0132-10AP/0TS-0AP-0AP- } \\
\text { 29AP-0AP }\end{array}$ \\
\hline 8 & PBW343 & $\begin{array}{l}\text { CM85836-4Y-0M-0Y-8M-0Y-0IND- } \\
\text { 0AP }\end{array}$ \\
\hline 9 & HUBARA-3*2/SHUHA-4 & $\begin{array}{l}\text { ICW04-20024-10AP-0AP-0AP-0AP- } \\
\text { 2AP-0AP }\end{array}$ \\
\hline 10 & UNIQUE 96/FLAG-1 & $\begin{array}{l}\text { ICW02-00330-11AP/0TS-0AP- } \\
\text { 030AP-1KUL-0 }\end{array}$ \\
\hline 11 & HUBARA-3*2/SHUHA-4 & $\begin{array}{l}\text { ICW04-20024-28AP-0AP-0AP-0AP- } \\
\text { 2AP-0AP }\end{array}$ \\
\hline 12 & $\begin{array}{l}\text { DAJAJ- } \\
\text { 5/4/CMH82A.1294/2*KAUZ/MUNIA/CHT }\end{array}$ & $\begin{array}{l}\text { ICW04-20101-17AP-0AP-0AP-0AP- } \\
\text { 3AP-0AP }\end{array}$ \\
\hline 13 & NESMA $* 2 / 14-2 / / 2 *$ SAFI-3 & $\begin{array}{l}\text { ICW00-0801-1AP-0AP-0AP- } \\
\text { 40AP/MOR-0AP }\end{array}$ \\
\hline 14 & MEXIPAK 65/ASFOOR-7 & ICW04-0359-8AP-0AP-0AP-4AP-0AP \\
\hline 15 & BT1735/ACHTAR//ASFOOR-1 & $\begin{array}{l}\text { ICW01-00164-0AP-11AP-0AP-0AP- } \\
\text { 2AP-110AP }\end{array}$ \\
\hline 16 & Sham6 & Registered and certified in Iraq \\
\hline 17 & Abu-Graib3 & Registered and certified in Iraq \\
\hline
\end{tabular}

1000 grains weight, harvest index $(\%)$, and grain yield per $/ 1 \mathrm{~m}^{2}(\mathrm{gm})$. The data of genotypes of the traits under study were analyzed according to the experimental design used and the differences between the means of the cultivation spaces between rows and the genotypes were compared by Duncan's multiple rang test method (Al-Zubaidy and Al-Falahy, 2016), and then phenotypic and genotypic variances $\left(\sigma_{\mathrm{P}}^{2}\right.$ and $\left.\sigma_{\mathrm{G}}^{2}\right)$ and phenotypic and genotypic covariance's $\left(\sigma \mathrm{P}_{\mathrm{x}} \mathrm{P}_{\mathrm{y}}\right.$ and $\left.\sigma \mathrm{G}_{\mathrm{x}} \mathrm{G}_{\mathrm{y}}\right)$ were estimated through the relationship between estimated and expected mean squares in the variance and Covariance analysis table, and then phenotypic and genotypic correlations were estimated between the traits under study from the following equations (Al-Zubaidi and Al-Jabouri, 2016). 
Mesopotamia J. of Agric.

ISSN: $2224-9796$ (Online)

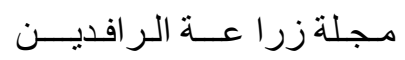

Vol. (48) No. (1) 2020

ISSN: $1815-316 \mathrm{X}$ (Print)

المجلد (48) العدد (1) 2020

Table (2): The amount of rainfall and supplementary irrigation for the agricultural season 2017-2018

\begin{tabular}{|c|c|c|c|c|}
\hline \multirow{2}{*}{ Month } & \multirow{2}{*}{$\begin{array}{l}\text { The amount of rain } \\
\text { falling }(\mathrm{mlm})\end{array}$} & \multicolumn{2}{|c|}{ sprinkled water (mlm) } & \multirow{2}{*}{ Total } \\
\hline & & The amount & Its date & \\
\hline \multirow{2}{*}{ December } & \multirow{2}{*}{7.81} & 20 & $14 / 12 / 2017$ & \multirow{2}{*}{47.81} \\
\hline & & 20 & $21 / 12 / 2017$ & \\
\hline \multirow{2}{*}{ January } & \multirow{2}{*}{12.69} & 20 & $11 / 1 / 2018$ & \multirow{2}{*}{52.69} \\
\hline & & 20 & $31 / 1 / 2018$ & \\
\hline February & 32.56 & 20 & $8 / 2 / 2018$ & 52.56 \\
\hline \multirow{2}{*}{ March } & \multirow{2}{*}{4.58} & 10 & $8 / 3 / 2018$ & \multirow{2}{*}{34.58} \\
\hline & & 20 & $29 / 3 / 2018$ & \\
\hline April & 14.04 & 20 & $5 / 4 / 2018$ & 34.04 \\
\hline May & 13.79 & ---- & $\begin{array}{ll}--- \\
-\end{array}$ & 13.79 \\
\hline Total & 85.47 & 150 & $\begin{array}{l}--- \\
-\end{array}$ & 235.47 \\
\hline
\end{tabular}

$r P=\sigma P_{x} P_{y} /\left[\sqrt{\left.\left(\sigma^{2} P_{x}\right)\left(\sigma^{2} P_{y}\right)\right]} ; \quad r G=\sigma G_{x} G_{y} /\left[\sqrt{\left.\left(\sigma^{2} G_{x}\right)\left(\sigma^{2} G_{y}\right)\right]}\right.\right.$

The path coefficient analysis established by Wright (1921) was approved to partition the coefficients of correlation (genetic and phenotypic) between the grain yield and some of its components to the two types of effects (direct and indirect) in the manner described by Dewey and Lu (1959) and then explained by Al-Rawi (1987) in detail to test the model

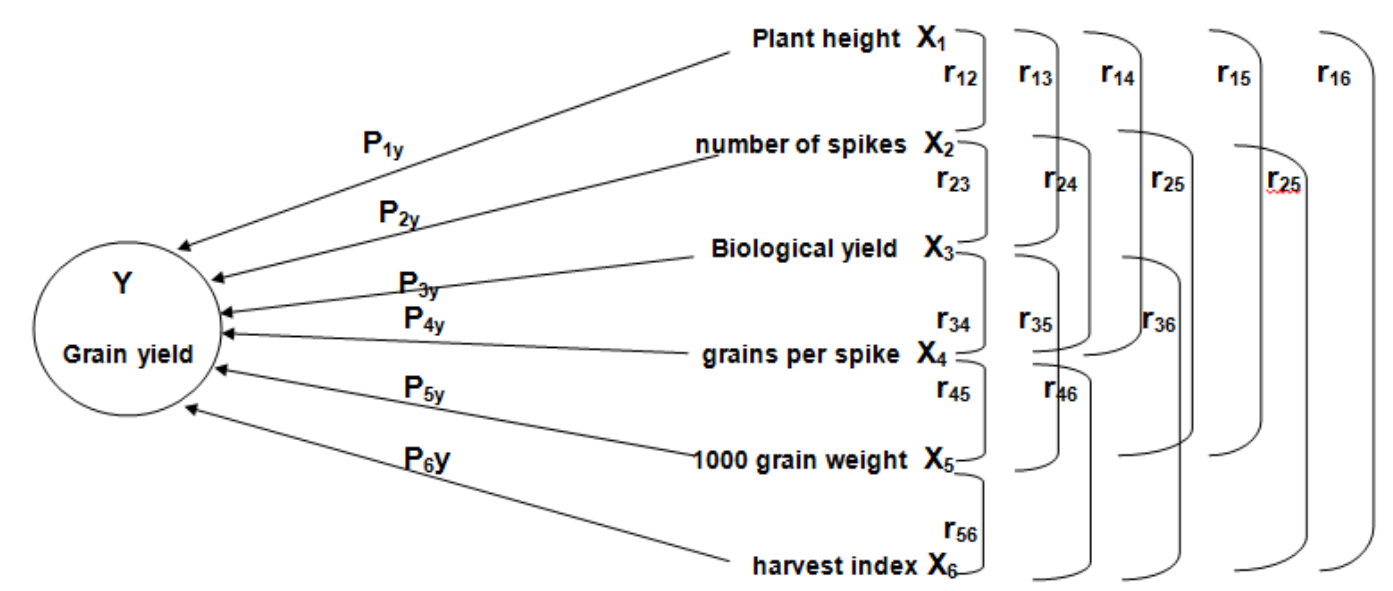

Figure 1: diagram of path way relationship for plant height $\left(X_{1}\right)$, number of spikes $\left(X_{2}\right)$, biological yield $\left(X_{3}\right)$, Number of grains per spike $\left(X_{4}\right), 1000$ grain weight $\left(X_{5}\right)$, and harvest index $\left(X_{6}\right)$ affecting the grain yield $(Y)$

which included six independent variables: Plant height $\left(\mathrm{x}_{1}\right)$, number of spikes $\mathrm{m}^{2}\left(\mathrm{x}_{2}\right)$, biological yield $\mathrm{gm} / \mathrm{m}^{2}\left(\mathrm{x}_{3}\right)$, grains number/spike $\left(\mathrm{x}_{4}\right), 1000$ grain weight $\left(\mathrm{x}_{5}\right)$ and the harvest index $\left(\mathrm{x}_{6}\right)$ as illustrated in the Figure (1). Direct effects (phenotypic and genetic) were estimated using correlation matrices as follows: $\mathrm{P}_{\mathrm{iy}}=\mathrm{R}^{-1} \mathrm{r}$, Where, $\mathrm{P}_{\mathrm{iy}}=$ direct effects vector, $\mathrm{R}^{-1}=$ inverse matrix of correlation coefficients between all possible pairs of traits and $r=$ correlation coefficient vector between grain yield and other traits. Following the 
Mesopotamia J. of Agric.

ISSN: $2224-9796$ (Online)

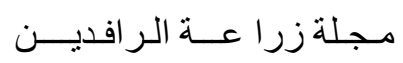

Vol. (48) No. (1) 2020

ISSN: $1815-316 \mathrm{X}$ (Print)

المجلد (48) العدد (1) 2020 (1)

path way shown in Figure 1, the direct and indirect effects (genetic and phenotypic) were estimated.

The significance of direct and indirect effects was determined according to the grading mentioned by Al-Zubaidy and Al-Jaboury (2016) as follows (from 0,00 - 0.09 neglected), (from 0.10 - 0.19 few), (from 0.20 - 0.29) moderate, (from 0,30 - 0,99) high and (more than $1,00)$ very high.

\section{RESULTS AND DICUSSION}

Table (3) shows the results of analysis of variance from the data of genotypes grown at three spaces between the rows for yield and some other traits in wheat. It is noted that the mean square of the genotypes was significant at a $1 \%$ probability level for plant height, number of grains per spike and 1000 grains weight only, and not significant for the other traits. This result is similar to what found by Ahmad et al. (2011) and Dawod et al. (2015) for these three traits.

Table (3): The analysis of variance results for grain yield and some other traits.

\begin{tabular}{|l|c|c|c|c|c|c|c|c|}
\hline & & \multicolumn{7}{|c|}{ Traits } \\
\cline { 3 - 9 } S. O. V. & d.f. & $\begin{array}{c}\text { Yield } \\
\left(\mathrm{gm} / \mathrm{m}^{2}\right)\end{array}$ & $\begin{array}{c}\text { Plant } \\
\text { Height } \\
(\mathrm{cm})\end{array}$ & $\begin{array}{c}\text { Number } \\
\text { spikes } \\
/ \mathrm{m}^{2}\end{array}$ & $\begin{array}{c}\text { Biologic } \\
\text { al yield } \\
\left(\mathrm{gm} / \mathrm{m}^{2}\right)\end{array}$ & $\begin{array}{c}\text { Number } \\
\text { grains } \\
\text { per } \\
\text { spike }\end{array}$ & $\begin{array}{c}1000 \\
\text { grains } \\
\text { weight } \\
(\mathrm{gm})\end{array}$ & $\begin{array}{c}\text { Harvest } \\
\text { index }\end{array}$ \\
\hline Reps. & 2 & 47615.8 & 336.49 & 32409.01 & 273492.5 & 861.05 & 78.23 & 477.74 \\
\hline Spaces & 2 & 80367.1 & 26.63 & 128825.2 & 599622.0 & 76.09 & 34.34 & 113.27 \\
\hline Error (a) & 4 & $8441.1^{*}$ & 153.08 & $4153.31^{*}$ & $82265.6^{*}$ & 214.95 & 86.94 & 200.44 \\
\hline Genotypes & 16 & 2816.1 & $103.89^{* *}$ & 2159.68 & 7695.1 & $122.38^{* *}$ & $74.21^{* *}$ & 94.24 \\
\hline S x G & 32 & 2561.8 & 35.952 & 1605.41 & $10935.5^{*}$ & 47.53 & 8.24 & 60.02 \\
\hline Error (b) & 96 & 1923.4 & 33.025 & 1606.74 & 6125.7 & 42.39 & 7.85 & 54.90 \\
\hline
\end{tabular}

- $\quad(* *)$ and $(*)$ significant at $1 \%$ and $5 \%$ respectively.

The mean squares data from the variance analysis of the traits under study and covariance between them were used to estimate the phenotypic and genetic variances of these traits, then these components were adopted in the calculations of genetic and phenotypic correlations as shown in Table 6. Table (4) shows the means of cultivation spaces between the rows as average of genotypes, and it is noted that the space $15 \mathrm{~cm}$ had highest means for the biological yield, spikes number and yield with a significant difference from the other two spaces, while the means of spaces for the rest of the traits were close and without significant differences between them, and the grain yield at $15 \mathrm{~cm}$ was higher than at 25 and $35 \mathrm{~cm}$ by $59.378 \%$ and $123.422 \%$ respectively. The means of genotypes for the different traits are shown as an average of the cultivation spaces in Table (5). The results of the Duncan's multiple range test show that there are significant differences between them for all traits except the biological yield (although $\mathrm{F}$ was not significant in the results of analysis of variance for grain yield, number of spikes and harvest index). The highest mean values for grain yield, plant height, number of spikes, biological yield, number of grain per spike, 1000 grain weight and harvest index were 126.88, 51.111, 134, 298.5, 33.621, 40.454 and 42.578 in genotypes 16 (i), 14, 16 (ii) and 13 (i), 5 (i), 13 (ii) and 5 (ii), respectively, while the lowest mean values were 60.33, 38.222, 97.19, 196.08, 17.022, 29.590 and 29.374 
Mesopotamia J. of Agric.

Vol. (48)

Table (4): Means of planting spaces between rows for grain yield and its components.

\begin{tabular}{|c|c|c|c|c|c|c|c|}
\hline \multirow{2}{*}{ Spaces } & \multicolumn{7}{|c|}{ Traits } \\
\cline { 2 - 8 } & $\begin{array}{c}\text { Yield } \\
\left(\mathrm{gm} / \mathrm{m}^{2}\right)\end{array}$ & $\begin{array}{c}\text { Plant } \\
\text { Height } \\
(\mathrm{cm})\end{array}$ & $\begin{array}{c}\text { Number } \\
\text { spikes } \\
/ \mathrm{m}^{2}\end{array}$ & $\begin{array}{c}\text { Biological } \\
\text { yield } \\
\left(\mathrm{gm} / \mathrm{m}^{2}\right)\end{array}$ & $\begin{array}{c}\text { Number } \\
\text { grains } \\
\text { per } \\
\text { spike }\end{array}$ & $\begin{array}{c}1000 \\
\text { grains } \\
\text { weight }\end{array}$ & $\begin{array}{c}\text { Harvest } \\
\text { index }\end{array}$ \\
\hline $15 \mathrm{~cm}$ & $140.89 \mathrm{a}$ & $45.176 \mathrm{a}$ & $188.67 \mathrm{a}$ & $377.09 \mathrm{a}$ & $26.028 \mathrm{a}$ & $34.257 \mathrm{a}$ & $36.749 \mathrm{a}$ \\
\hline $25 \mathrm{~cm}$ & $88.40 \mathrm{~b}$ & $43.804 \mathrm{a}$ & $121.18 \mathrm{ab}$ & $223.48 \mathrm{ab}$ & $28.359 \mathrm{a}$ & $34.038 \mathrm{a}$ & $38.225 \mathrm{a}$ \\
\hline $35 \mathrm{~cm}$ & $63.06 \mathrm{~b}$ & $44.098 \mathrm{a}$ & $90.42 \mathrm{~b}$ & $167.72 \mathrm{~b}$ & $26.560 \mathrm{a}$ & $35.556 \mathrm{a}$ & $35.244 \mathrm{a}$ \\
\hline
\end{tabular}

- The values followed by the same letter for each trait are not significantly different.

Table (5): Means of genotypes for grain yield and its components.

\begin{tabular}{|c|c|c|c|c|c|c|c|}
\hline \multirow{2}{*}{ Genotypes } & \multicolumn{7}{|c|}{ Traits } \\
\cline { 2 - 8 } & $\begin{array}{c}\text { Yield } \\
\text { gm/m }\end{array}$ & $\begin{array}{c}\text { Plant } \\
\text { Height } \\
(\mathrm{cm})\end{array}$ & $\begin{array}{c}\text { Number } \\
\text { spikes } \\
/ \mathrm{m}^{2}\end{array}$ & $\begin{array}{c}\text { Biological } \\
\text { yield } \\
\left(\mathrm{gm} / \mathrm{m}^{2}\right)\end{array}$ & $\begin{array}{c}\text { Number } \\
\text { grains } \\
\text { per } \\
\text { spike }\end{array}$ & $\begin{array}{c}1000 \\
\text { grains } \\
\text { weight }\end{array}$ & $\begin{array}{c}\text { Harvest } \\
\text { index }\end{array}$ \\
\hline 1 & $112.7 \mathrm{ab}$ & $44.111 \mathrm{~b}-\mathrm{e}$ & $150.29 \mathrm{ab}$ & $282.78 \mathrm{a}$ & $25.91 \mathrm{~b}$ & $34.846 \mathrm{cde}$ & $40.166 \mathrm{ab}$ \\
\hline 2 & $82.79 \mathrm{abc}$ & $44.389 \mathrm{~b}-\mathrm{e}$ & $122.34 \mathrm{abc}$ & $230.56 \mathrm{a}$ & $25.548 \mathrm{~b}$ & $32.203 \mathrm{ef}$ & $34.177 \mathrm{bc}$ \\
\hline 3 & $112.5 \mathrm{ab}$ & $46.778 \mathrm{abc}$ & $138.91 \mathrm{abc}$ & $288.86 \mathrm{a}$ & $31.02 \mathrm{ab}$ & $33.132 \mathrm{de}$ & $36.162 \mathrm{abc}$ \\
\hline 4 & $98.95 \mathrm{abc}$ & $41.722 \mathrm{cde}$ & $125.79 \mathrm{abc}$ & $262.75 \mathrm{a}$ & $27.53 \mathrm{ab}$ & $33.290 \mathrm{de}$ & $34.901 \mathrm{abc}$ \\
\hline 5 & $114.7 \mathrm{ab}$ & $41.500 \mathrm{cde}$ & $152.27 \mathrm{ab}$ & $272.05 \mathrm{a}$ & $33.621 \mathrm{a}$ & $32.648 \mathrm{de}$ & $42.578 \mathrm{a}$ \\
\hline 6 & $91.00 \mathrm{abc}$ & $44.611 \mathrm{bcd}$ & $134.90 \mathrm{abc}$ & $237.79 \mathrm{a}$ & $27.04 \mathrm{ab}$ & $31.989 \mathrm{ef}$ & $36.071 \mathrm{abc}$ \\
\hline 7 & $74.62 \mathrm{bc}$ & $38.222 \mathrm{e}$ & $115.49 \mathrm{bc}$ & $226.72 \mathrm{a}$ & $24.46 \mathrm{ab}$ & $33.143 \mathrm{de}$ & $34.525 \mathrm{abc}$ \\
\hline 8 & $107.8 \mathrm{abc}$ & $44.722 \mathrm{bcd}$ & $125.51 \mathrm{abc}$ & $273.65 \mathrm{a}$ & $28.89 \mathrm{ab}$ & $38.184 \mathrm{ab}$ & $38.639 \mathrm{ab}$ \\
\hline 9 & $109.1 \mathrm{abc}$ & $41.889 \mathrm{cde}$ & $135.60 \mathrm{abc}$ & $262.00 \mathrm{a}$ & $31.32 \mathrm{ab}$ & $33.507 \mathrm{de}$ & $40.127 \mathrm{ab}$ \\
\hline 10 & $73.17 \mathrm{bc}$ & $45.556 \mathrm{a}-\mathrm{d}$ & $97.19 \mathrm{c}$ & $196.08 \mathrm{a}$ & $24.535 \mathrm{~b}$ & $38.199 \mathrm{ab}$ & $25.781 \mathrm{abc}$ \\
\hline 11 & $90.09 \mathrm{abc}$ & $48.611 \mathrm{ab}$ & $124.46 \mathrm{abc}$ & $250.43 \mathrm{a}$ & $25.311 \mathrm{~b}$ & $37.244 \mathrm{bc}$ & $34.592 \mathrm{abc}$ \\
\hline 12 & $89.80 \mathrm{abc}$ & $42.111 \mathrm{cde}$ & $127.60 \mathrm{abc}$ & $242.10 \mathrm{a}$ & $27.36 \mathrm{ab}$ & $35.430 \mathrm{bcd}$ & $36.388 \mathrm{abc}$ \\
\hline 13 & $114.06 \mathrm{ab}$ & $44.889 \mathrm{bcd}$ & $138.55 \mathrm{abc}$ & $298.58 \mathrm{a}$ & $24.065 \mathrm{~b}$ & $40.454 \mathrm{a}$ & $37.283 \mathrm{abc}$ \\
\hline 14 & $98.97 \mathrm{abc}$ & $51.111 \mathrm{a}$ & $131.47 \mathrm{abc}$ & $257.83 \mathrm{a}$ & $27.64 \mathrm{ab}$ & $35.576 \mathrm{bcd}$ & $37.672 \mathrm{abc}$ \\
\hline 15 & $99.24 \mathrm{abc}$ & $45.722 \mathrm{abc}$ & $264.35 \mathrm{a}$ & $264.35 \mathrm{a}$ & $27.73 \mathrm{ab}$ & $31.838 \mathrm{ef}$ & $34.499 \mathrm{abc}$ \\
\hline 16 & $126.88 \mathrm{a}$ & $45.944 \mathrm{ab}$ & $269.672 \mathrm{a}$ & $269.48 \mathrm{a}$ & $29.67 \mathrm{ab}$ & $37.225 \mathrm{bc}$ & $41.698 \mathrm{ab}$ \\
\hline 17 & $60.33 \mathrm{c}$ & $39.222 \mathrm{de}$ & $210.65 \mathrm{a}$ & $210.65 \mathrm{a}$ & $17.022 \mathrm{c}$ & $29.590 \mathrm{f}$ & $29.374 \mathrm{c}$ \\
\hline
\end{tabular}

- The values followed by the same letter for each trait are not significantly different.

in genotypes 17 (i), 7, 10 (i), 10 (ii), 17 (ii), 17 (iii) and 17 (iv), respectively, and It is evident that some genotypes gave distinct results for the most number of traits, including grain yield, in the foreground, Genotypes 14 and 16, followed by genotypes 8, 13 and 15, and these results indicate the possibility of utilizing these distinct genotypes in hybridization breeding programs in the future in order to transfer desirable traits to local varieties that adapted to environmental conditions, as well as in the development of new varieties of bread wheat. From previous studies, other researchers obtained significant differences between the means of genotypes for grain yield and their components in wheat, including 
Mesopotamia J. of Agric.

Vol. (48) No. (1) 2020
ISSN: 2224 - 9796 (Online)

ISSN: $1815-316 \mathrm{X}$ (Print)

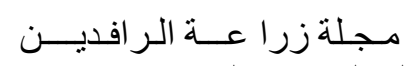

المجلد (48) العدد (1) 2020 (1)

Kalapana et al. (2014), Esmail et al. (2016) and Bhattarai et al. (2017). Table (6) shows the values of genetic and phenotypic correlation coefficients between pairs of traits. It is noted that both types of correlations were similar in strength and direction for most cases, and that genetic correlations increase in value over most of the phenotypic one, and It is evident that grain yield/unit area correlated positively and significantly (genetically and phenotypically) with plant height, biological yield, number of grains/spike, weight of 1000 grains and harvest index, and phenotypically with number of spikes/unit area, indicating that the first five traits are genetically associated with the grain yield. The genetic correlation (which was negative) between yield and number of spike/unit area did not reach the significant level. On the other hand, no significant genetic correlations (whether negative or positive) were shown for plant height with both the biological yield and number of grains per spike, for the number of spikes per unit area with the number of grains per spike and for the number of grains per spike with 1000 grain weight, and phenotypically for number of spikes per unit area with both plant height and weight of 1000 grain and for number of grains/spike with the weight of 1000 grains. This independent association of these traits with the grain yield per unit area is generally beneficial to crop breeders, this is because if any of these traits are heavily selected in early generations, there is less possibility of excluding offspring that yielded well, if they are negatively correlated.

Table (6): Genetic correlations (above) and phenotypic (below) between the grain yield of bread wheat and some of its components.

\begin{tabular}{|l|c|c|c|c|c|c|c|}
\hline \multicolumn{1}{|c|}{ Traits } & $\begin{array}{c}\text { Yield } \\
\left(\mathrm{gm} / \mathrm{m}^{2}\right)\end{array}$ & $\begin{array}{c}\text { Plant } \\
\text { height } \\
(\mathrm{cm})\end{array}$ & $\begin{array}{c}\text { Number } \\
\text { spikes } \\
/ \mathrm{m}^{2}\end{array}$ & $\begin{array}{c}\text { Biological } \\
\text { yield } \\
\left(\mathrm{gm} / \mathrm{m}^{2}\right)\end{array}$ & $\begin{array}{c}\text { Number } \\
\text { grains } \\
\text { per } \\
\text { spike }\end{array}$ & $\begin{array}{c}1000 \\
\text { grains } \\
\text { weight }\end{array}$ & $\begin{array}{c}\text { Harvest } \\
\text { index }\end{array}$ \\
\hline Yield $\left(\mathrm{gm} / \mathrm{m}^{2}\right)$ & 1 & $0.248^{*}$ & -0.044 & $0.786^{* *}$ & $0.876^{* *}$ & $0.419 * *$ & $1.371^{* *}$ \\
\hline Plant height $(\mathrm{cm})$ & $0.471^{* *}$ & 1 & $-0.339 * *$ & 0.116 & -0.006 & $0.451 * *$ & 0.028 \\
\hline Number spikes $/ \mathrm{m}^{2}$ & $0.668^{* *}$ & 0.140 & 1 & $-0.643 * *$ & 0.009 & $-0.629 * *$ & $0.625 * *$ \\
\hline Bio. yield $\left(\mathrm{gm} / \mathrm{m}^{2}\right)$ & $0.841^{* *}$ & $0.403^{* *}$ & $0.587^{* *}$ & 1 & $-3.692^{* *}$ & $-4.224 * *$ & $1.627 * *$ \\
\hline Number grains/spike & $0.722^{* *}$ & $0.268^{* *}$ & $0.293^{* *}$ & $-0.686^{* *}$ & 1 & -0.022 & $0.919^{* *}$ \\
\hline 1000 grains weight & $0.412^{* *}$ & $0.468^{* *}$ & -0.088 & $-1.193 * *$ & 0.097 & 1 & $1.996^{* *}$ \\
\hline Harvest index $(\%)$ & $0.869 * *$ & $0.269^{* *}$ & $0.609^{* *}$ & $0.655^{* *}$ & $0.799 * *$ & $2.431 *$ & 1 \\
\hline
\end{tabular}

- $(* *)$ and $(*)$ significant at $1 \%$ and $5 \%$ respectively.

In order to determine the most influential traits in the grain yield for use in breeding programs for selection of high yield, the simple correlation coefficients (genetic and phenotypic) of yield with the other traits were hashed to the direct and indirect effects through the adoption of path analysis technique, and it was noted from genetic path analysis (Table 7), that the direct effect of plant height in yield was low, while the indirect effect through number of spikes was highly positive and through 1000 grain weight highly negative, and not important through other traits. The direct effect of number of spikes in the grain yield was negative and high, whereas the indirect effects through 1000 grains weight and harvesting index were positive and high and through the biological yield highly negative and not important through other traits. The direct genetic effect of the biological yield was positive and high in the grain yield, and the indirect effects were positive high through the number of spikes and very high through 1000 grains weight and harvest index, 
Mesopotamia J. of Agric.

Vol. (48) No. (1) 2020
ISSN: $2224-9796$ (Online)

ISSN: $1815-316 \mathrm{X}$ (Print)

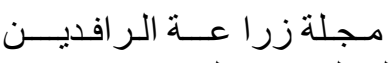

المجلد (48) العدد (1) 2020

Table (7): Genetic path analysis for traits affecting grain yield

\begin{tabular}{|l|c|c|c|c|c|c|c|}
\hline \multicolumn{1}{|c|}{ Traits } & $\begin{array}{c}\text { Plant } \\
\text { height } \\
(\mathrm{cm})\end{array}$ & $\begin{array}{c}\text { Number } \\
\text { spikes } \\
/ \mathrm{m}^{2}\end{array}$ & $\begin{array}{c}\text { Biological } \\
\text { yield } \\
\left(\mathrm{gm} / \mathrm{m}^{2}\right)\end{array}$ & $\begin{array}{c}\text { Number } \\
\text { grains } \\
\text { per } \\
\text { spike }\end{array}$ & $\begin{array}{c}1000 \\
\text { grains } \\
\text { weight }\end{array}$ & $\begin{array}{c}\text { Harvest } \\
\text { index }\end{array}$ & $\begin{array}{c}\text { Correlation } \\
\text { with yield }\end{array}$ \\
\hline plant height $(\mathrm{cm})$ & $(0.176)$ & 0.317 & 0.055 & -0.009 & -0.326 & 0.035 & $0.278^{*}$ \\
\hline No. spikes $/ \mathrm{m}^{2}$ & -0.059 & $(-0.936)$ & -0.307 & 0.013 & 0.456 & 0.791 & -0.044 \\
\hline Bio. yield $\left(\mathrm{gm} / \mathrm{m}^{2}\right)$ & 0.021 & 0.602 & $(0.478)$ & -5.432 & 3.059 & 2.059 & $0.786^{* *}$ \\
\hline No. grains/spike & -0.001 & -0.008 & -1.765 & $(1.471)$ & 0.016 & 1.164 & $0.876^{* *}$ \\
\hline 1000 grains weight & 0.079 & 0.589 & -2.019 & -0.032 & $(-0.724)$ & 2.525 & $0.419^{* *}$ \\
\hline Harvest index $(\%)$ & 0.005 & -0.585 & 0.778 & 1.353 & -1.445 & $(1.265)$ & $1.371^{* *}$ \\
\hline
\end{tabular}

- $(* *)$ and $(*)$ significant at $1 \%$ and $5 \%$ respectively.

and negative very high through the number of grains per spike, but not important through plant height. The direct effects of number of grains/spike and harvesting index in the yield was positive and very high and it reached 1.4709 and 1.2651 respectively, and at the same time, the correlation of these two traits with the yield was highly significant and close to one, while the indirect effect of the number of grains per spike was positive very high through the harvest index, as well as the indirect effect of the harvest index was positively high through the biological yield and very high through the number of grain per spike. Finally, the direct genetic effect of the weight of 1000 grains in the yield get negative and very high, while the indirect effect was highly positive through the number of spikes and very high through harvest index. From the results of the phenotypic pathway analysis shown in Table (8), it is noticed that the direct effects on grain yield were negative low for plant height, and high for the number of spikes and 1000 grains weight, while the indirect effect of plant height was moderately positive through the number of grains per spike and harvest index and high through the biological yield, and the indirect one of the spikes number is positive, medium through the number of grains per spike and high through the biological yield and harvest index, while the indirect effect of 1000 grains weight was

Table (8): Phenotypic path analysis for traits affecting grain yield

\begin{tabular}{|l|c|c|c|c|c|c|c|}
\hline \multicolumn{1}{|c|}{ Traits } & $\begin{array}{c}\text { Plant } \\
\text { height } \\
(\mathrm{cm})\end{array}$ & $\begin{array}{c}\text { Number } \\
\text { spikes } \\
/ \mathrm{m}^{2}\end{array}$ & $\begin{array}{c}\text { Biological } \\
\text { yield } \\
\left(\mathrm{gm} / \mathrm{m}^{2}\right)\end{array}$ & $\begin{array}{c}\text { Number } \\
\text { grains } \\
\text { per } \\
\text { spike }\end{array}$ & $\begin{array}{c}1000 \\
\text { grains } \\
\text { weight }\end{array}$ & $\begin{array}{c}\text { Harvest } \\
\text { index }\end{array}$ & $\begin{array}{c}\text { Correlation } \\
\text { with yield }\end{array}$ \\
\hline Plant height $(\mathrm{cm})$ & $(-0.118)$ & -0.098 & 0.376 & 0.252 & -0.174 & 0.233 & $0.471^{* *}$ \\
\hline No. spikes $/ \mathrm{m}^{2}$ & -0.017 & $(-0.700)$ & 0.548 & 0.276 & 0.033 & 0.529 & $0.668^{* *}$ \\
\hline Bio. Yield $\left(\mathrm{gm} / \mathrm{m}^{2}\right)$ & -0.048 & -0.411 & $(0.933)$ & -0.645 & 0.444 & 0.569 & $0.841^{* *}$ \\
\hline No. grains/spike & -0.032 & -0.205 & -0.639 & $(0.941)$ & -0.036 & 0.694 & $0.723^{* *}$ \\
\hline 1000 grains weight & -0.055 & 0.062 & -1.113 & 0.092 & $(-0.372)$ & 2.109 & $0.723^{* *}$ \\
\hline Harvest index $(\%)$ & -0.032 & -0.427 & 0.611 & 0.753 & -0.904 & $(0.868)$ & $0.869 * *$ \\
\hline
\end{tabular}

- (**) significant at $1 \%$. 
Mesopotamia J. of Agric.

ISSN: $2224-9796$ (Online)

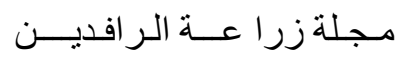

Vol. (48) No. (1) 2020

ISSN: $1815-316 \mathrm{X}$ (Print)

المجلد (48) العدد (1) 2020

positive very high through harvest index. The direct phenotypic effect of the other traits (biological yield, grains number/spike and the harvest index) was highly positive, and respectively, reaching $0.933,0.941$ and 0.868 , whereas the indirect effect of the biological yield was positive and high through the weight of 1000 grains and index harvest, and the indirect one of grains number/spike was positive and high through the harvest index, while the indirect effect of the harvest index was positive and high through the biological yield and number of grains per spike.

It is noted from the foregoing that the highest direct and indirect effects through other traits in grain yield (genetically and phenotypically) were for the number of grains per spike and harvest index, followed in importance by biological yield, and it is therefore possible to rely on these three traits as selection indices for the high grain yield in breeding programs. From previous studies, Ayerl et al. (2017), Sapi et al. (2017) and Kamani (2017) concluded that path analysis explain the significance of the direct effect on yield/plant which appeared higher through biologic yield and index harvest. Dutamo et al. (2015), from their experiment that carried out in one location, indicated that despite the direct and indirect effects of the harvest index and biological yields, and the possibility of their adoption in the selection of high grain yield, but this is not a final conclusion only after repeated implementation of the experiment in multiple locations. Khan and Dar (2010) indicated that the significance of the positive direct effect on grain yield was higher by the spikes number/plant, followed by the grains number/spike and weight of 100 grains, while the study of Desheva (2016) showed that the two traits, number of grains per spike and 1000 grains weight through grain weight per spike had the highest positive indirect effect on grain yield per plant, and this relationship can be used as a selection index in breeding programs to improve high-yielding varieties.

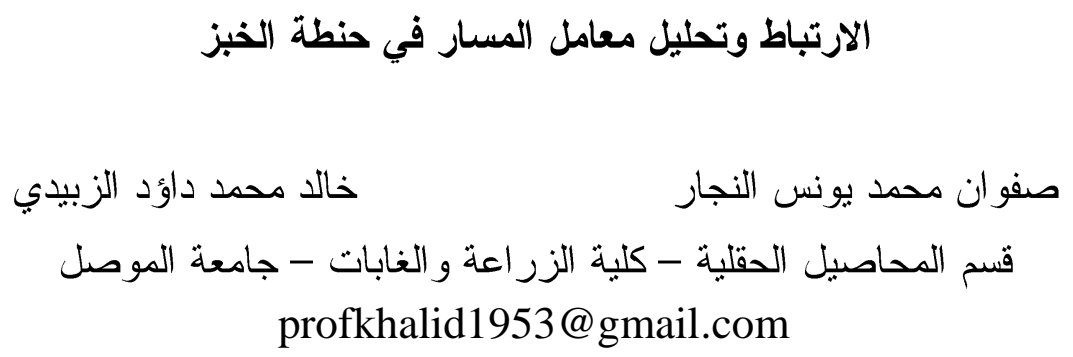

الخلاصة

نم زراعة 15 نزكيب وراثي من حنطة الخبز بالإضافة الى الصنفين المعتمدين في العراق (شام6 و ابو غريب3) داخل حرم جامعة الموصل عند ثلاث مسافات للزر اعة بين الخطوط (15 25 و35سم) باستخدام نظام الالو اح المنشقة بتصميم قطاعات عشو ائية كاملة بثلاثة مكررات لتقييم صفات حاصل الحبوب وبعض مكوناته من الصفات الأخرى (ارتفاع النبات وعدد السنابل وعدد الحبوب بالسنبلة و الحاصل الحيوي ووزن 1000حبة ودليل

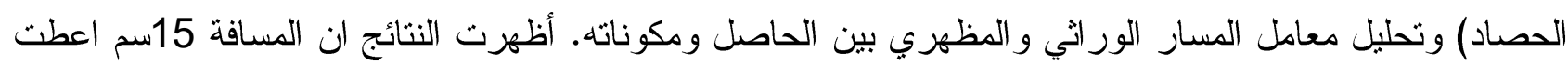
اعلى المتوسطات لصفات الحاصل الحيوي وعدد السنابل وحاصل الحبوب، وكان حاصل الحبوب عندها اعلى مما هو عليه عند المسافتين 25 و35 35م بنسبة 123.422 \% 59.378 على التو الي. تقوقت بعض التز اكيب الور اثية

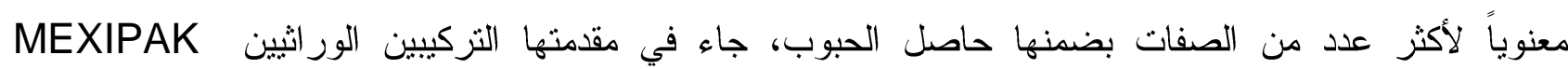


Mesopotamia J. of Agric.

Vol. (48) No. (1) 2020
ISSN: $2224-9796$ (Online)

ISSN: $1815-316 \mathrm{X}$ (Print)

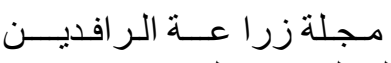

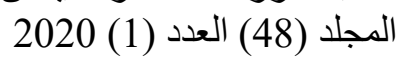

NESMA*2/14-2//2*SAFI- و PBW343 65/ASFOOR-7 وشام6 نلاهما التز اكيب الوراثية

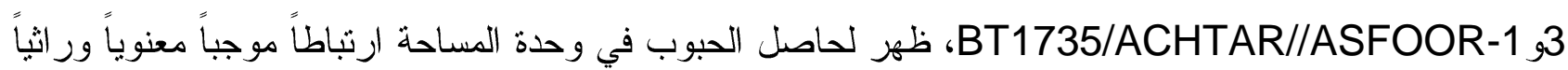

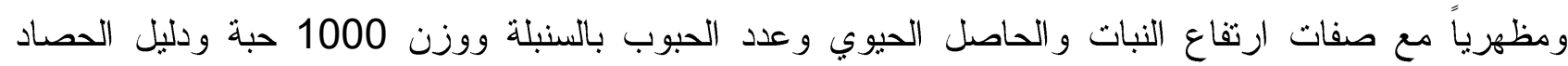

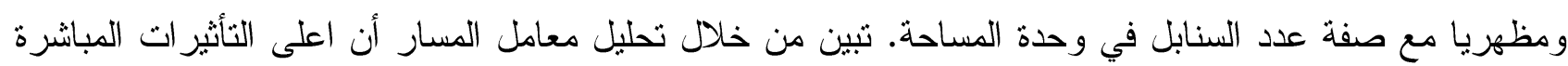

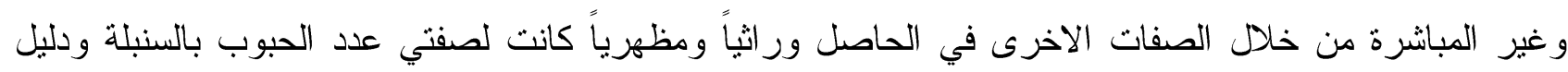
الحصاد وتلتهما في الاهمية صفة الحاصل الحيوي، وعليه بالإمكان الاعتماد على هذه الصفات الثلاث كأدلة انتخابية للحاصل العالي في بر امج التزبية.

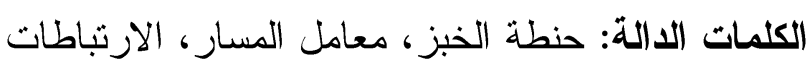
تاريخ تسليم البحث: 8 / 1 / 2020 ، وقبوله: 3 / / 3 / 3 /

\section{REFERENCES}

Ahmad F., S. Khan, S. Q. Ahmad, H. Khan, A. Khan and F. Muhammad (2011). Genetic analysis of some quantitative traits in bread wheat across environments. African $J$. Agric. Res., 6(3): 686-692.

Al-Rawi, Kh. M.(1987). Introduction to Regression Analysis, Dar Al Kutub Directorate for Printing and Publishing, Mosul University, Iraq. (in Arabic)

Al-Zubaidy, Kh. M. D. and Kh. Kh. A. Al-Juboury (2016). Design and Analysis of Genetical Experiments. Dar Al Wadah Publishing House, Jordan - Amman, Dijla Library for Printing, Publishing and Distribution, Republic of Iraq - Baghdad. (in Arabic)

Al-Zubaidy, K. M. D. and M. A. H. Al-Falahy (2016). Principles and Proceedures of Statistics and Experimental Designs. Duhok University Press, Iraq.

Ayer, D. K., A. Sharma, B. R. Ojha, A. Paudel and K. Dhakal. (2017).Correlation and path coefficient analysis in advanced wheat genotypes. SAARC J. Agri., 15(1): 1-12.

Bhattarai, R. P., B. R. Ojha, D. B. Thapa, R. Khareh, A. Ojha and M. Sapkota (2017). Evaluation of elite spring wheat (Triticum aestivum L.) genotypes for yield. and yield attributing traits under irrigated condition. Int. J. Appl. Sci. Biotechnol. 5(2): 194-202.

Dawod, K. M., M. A. H. Al-Falahy and A. S. A. Mohammad (2015). Evaluation of introduced bread wheat genotypes through selection index technique. Dohok Univ. J., 15(1): 120-127.

Desheva, G. (2016). Correlation and path-coefficient analysis of quantitative characters in winter bread wheat varieties. Trakia Journal of Sciences, 1: 24-29.

Dewey, D. R. and K. H. Lu (1959). A correlation and path coefficient analysis of component of crested Wheat grass seed production. Agron. J. V.(5): 515-518.

Diz D. A., D. S. Wofford, S. C. Schank (1994). Correlation and path coefficient analyses of seed-yield components in pearl millet $\times$ elephant grass hybrids. Theor. Appl. Genet., 89: 112-115.

Dutamo, D., S. Alamerew, F. Eticha and E. Assefa (2015). Path coefficient and correlation studies of yield and yield associated traits in bread wheat (Triticum aestivum L.) germplasm. World Applied Sci. J. 33 (11): 1732-1739. 
Mesopotamia J. of Agric. $\quad$ ISSN: $2224-9796$ (Online) Vol. (48) No. (1) $2020 \quad$ ISSN: $1815-316$ X (Print)

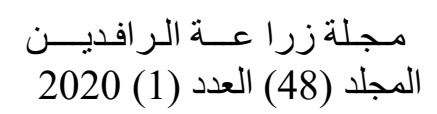

Esmail, R. M., S. E. I. Eldessouky, S. A. Mahfouze and I. S. El-Demardash (2016).

Evaluation of new bread wheat lines (Triticum aestivum L) under normal and water stress conditions. Int. J. ChemTech Res., 9(5): 89-99.

Hussain K., I. A. Khan, H. A. Sadaqt and M. Amjad (2010). Genotypic and phenotypic correlation analysis of yield and fiber quality determining traits in upland cotton (Gossypim hirsutum). Int. J. Agric. Biol. 12: 348-352.

Kalapana, A., P. Prusty and S. K. Mukhopadhyay (2014). Performance of wheat genotypes under different row spacing in New Alluvial Zone of West Bengal. J. Crop and Weed, 10(2): 480-485.

Kale U.V., H. V. Kalpande, S. N. Annapurve and V. K. Gite (2007). Yield components analysis in American Cotton (Gossypium hirsutum L.). Madras Agric. J. 94 (7-12): 156-161.

Kamani, D. L., C. A.Babariya and P. B.Marviya (2017). Correlation coefficient and path coefficient analysis for yield components in wheat (Triticum aestivum L.). Int. J. Pure App. Biosci. 5 (5): 545-552.

Kang,M. S.,J. D.Miller and P.Y. P.Tai (1983). Genetic and phenotypic path analysis and heritability in sugarcane. Crop Sci. 23: 643-647.

Khan, M. H. and A. N. Dar (2010). Correlation and path coefficient analysis of some quantitative traits in wheat. African Crop Science Journal, 18(1): $9-14$.

Pandey J. P. and J. H. Torrie (1973). Path coefficient analysis of seed yield components in soybeans (Glycine max L. Merr.). Crop Sci. 13: 505-507.

Sapi, Sh., M. Shailesh and I.Bhattacharjee (2017). Correlation and path coefficient analysis of some quantitative traits in bread wheat. J. Pharmacognosy and Phytochemistry 6(4): 258-262.

Wright, S. (1921). Correlation and causation. J. Agric. Res. 20: 557-585. 